DOI https://doi.org/10.30525/978-9934-26-117-6-16

\title{
ДЕЯКІ РИСИ ОСОБИСТІСНОГО ПОРТРЕТУ УКРАЇНСЬКОГО КОМПОЗИТОРА ЯКОВА ЯЦИНЕВИЧА
}

\author{
Чамахуд Д. В. \\ магістр кафедри історії украӥнської музики \\ та музичної фольклористики \\ Національна музична академія України імені П. І. Чайковського \\ м. Київ, Україна
}

Композиторам XXI століття неважко зберігати інформацію не лише про свою творчість, а й про власні життєві перепитії, стосунки з оточуючими і т. Д. Для цього у нагоді стають відеозаписи, численні фото, висловлювання у постах у соціальних мережах, які легко дублювати. Цього не скажеш про діячів минулих епох. Саме тому музикознавцям доводиться докласти чимало зусиль, щоб дослідити особисті якості та хоча б трішки зрозуміти, якою людиною був митець. Нерідко відомості про видатних постатей вдається відшукати лише в архівних фондах. Серед таких особистостей - український композитор Яків Михайлович Яциневич (1869-1945), музична спадщина якого тривалий час була під забороною.

У процесі дослідження життєтворчості Я. Яциневича постає проблема «особистість - творчість». Особистість, за визначенням Ю. Чекана, - «стала система соціально значимих ознак, якими характеризується індивід» [9, с. 52]. Наразі із опублікованих спогадів сучасників композитора дізнаємося лише про його діяльність, відомостей про Я. Яциневича саме як про особистість, відносини 3 іншими митцями, майже немає. Проте серед архівних документів у Центральному державному архіві-музеї літератури і мистецтва України та Інституті рукопису Національної бібліотеки України імені В. І. Вернадського вдалося натрапити на епістолярні знахідки (листи дружини композитора Ірини Яциневич [4; 5], а також його власні [3]). Саме ці матеріали допомагають виявити окремі особистісні риси композитора.

3 реконструкції біографії Я. Яциневича з'ясовуємо, що упродовж життя митець займався різноманітною діяльністю: насамперед композиторська праця, яку поєднував з роботою диригента і музичного педагога (викладав фортепіано, музично-теоретичні дисципліни), фольклористична практика, організовував церковні, міські, любительські й студентські хори, акомпанував хорам, ансамблям та солістам у концертах, працював при видавничому відділі Всеукраїнської православної церковної ради, брав активну участь у громадському 
житті і в діяльності Української автокефальної православної церкви, був священиком, а також трудився на різноманітних немузичних роботах як інженер, будівельник, діловод й на інших посадах. Зважаючи на зазначений перелік видів праці, а також іiі значні масштаби, можна зробити висновок про полідіяльнісний тип особистості Я. Яциневича, у якій переважають композиторська та диригентська робота. Такий тип митця, який активно поєднував не лише різні напрями творчості, але й громадську діяльність, за визначенням Л. Корній, можна віднести до романтичного [2, с. 171].

Дружина композитора згадує про Я. Яциневича як про людину 3 високими моральними якостями. Незважаючи на відкриту ворожість 3 боку інших митців, Я. Яциневич завжди залишався благородним по відношенню до них, вважав за краще відступити, аніж сваритися. Про це свідчать листи І.Яциневич від 27 лютого 1961 р.: «Вообще об истории дорогого моего мужа я не могу говорить спокойно. <...>. А он был самый благородный, скромный человек» [5, арк. 23в.] та 28-29 квітня 1965 р.: «Тогда Яков Михайлович, как противник интриг бросил прекрасную капеллу в 75 человек $и$ как инженер с двадиатилетним стажем уехал на Запорожье» [5, арк. 123в.-13]. Наведені спогади дружини митця вказують на перевагу у поведінці Я. Яциневича інтровертної установки сприйняття світу за теорією К. Юнга ${ }^{11}$, тобто орієнтації не на об'єкт, а на суб'єктивні фактори, заглиблення у внутрішній світ, переживання емоцій всередині себе $[10$, с. 201$]$.

Я. Яциневич завжди зберігав толерантність у своїх висловлюваннях до ворогів та вмів цінувати їх творчі здобутки, що дізнаємося із його листа до недруга М. Вериківського (від 16 жовтня 1925 р.): «Високочановний т. Вериківський! Не відмовте, будь ласка, прислать мені яко мога скоріше Ваш хор «Прапор червоний» <...>. 3 великою пошаною Я. Яииневич» [6, арк. 12]. Незважаючи на важкі життєві обставини, композитор вмів помічати інші радості оточуючого світу. У листі до П. Тичини від 2 липня 1942 р. Я. Яциневич висловлює сподівання на краще майбутнє: «B ией час, коли я пишу цьього листа, йде благодатний дощ, якого не було тут иілий місяиь, а тому було побоювання, щчо коли й надалі так продовжиться, то користи від иього не ждать. I от дощ приніс нам радість і надію. Хай же буде ие

${ }^{11}$ Швейцарський психолог, психіатр, філософ К. Юнг (1875-1961) у своїй праці «Психологічні типи» (1921) виділяє екстраверсійний та інтровесійний типи особистості. У кожному типі К. Юнг виділяє ще по чотири групи (разом їх вісім), зважаючи на перевагу у них мислення, почуття, відчуття чи інтуїції, тобто однієї з основних психологічних функцій. 66 
символом кращого майбутнього нашої дорогої Украӥни... 3 глибокою вдячністю й щирою пошаною до Вас Я. Ячиневич» [3, арк. 1зв.-2].

Упродовж життя композитор завжди старанно виконував свою роботу, навіть якщо не отримував відповідних коштів за це. Свідчення - записи старости хору Університету святого Володимира О. Володського (від 26 жовтня 1904 р.): «Регент Я. М. Яииневич, безвозмездно уделяя нам свои досуги, аккуратно исполняя свои обязанности в течении почти двух лет, обратился к нам с просьбой поддержать его несколько» [7, арк. 13 зв.], а також довідка композитора про роботу в Одесі (від 13 лютого 1926 р.): «В дійсності прачя тов. Яииневича забірає далеко більше часу, але добавочної платні за це він від Політосвіти не одержує» [1, арк. 8].

У прагненні Я. Яциневича до братерської взаємоповаги, залишатися собою у будь-яких ситуаціях, виявляються гуманістичні риси особистості, які, за соціонічною типологією ${ }^{12}$, описаною К. Філатовою (на основі вчення К. Юнга, 3. Фрейда, А. Кемпінського), характерні для етико-інтуїтивного інтроверта [8, с. 124]. К. Філатова зазначає, що поняття «Гуманіст» визначає «людину, для якої головним у житті $\epsilon$ судження про добро і зло, моральність і неморальність, порядність i непорядність» [8, с. 125]. Для людей такого типу важливими є етичні правила, загальноприйняті для усіх, вони характеризуються увагою до кожного, чуйністю до чужих проблем і обов'язковим виявом підтримки у справах та допомозі. Гуманісти дуже вразливі та емоційно сприйнятливі, усі проблеми переносять внутрішньо, вміло втамовують гнів та роздратування $[8$, с. $125-127]$. Окрім того, гуманісти можуть займатися будь-якими видами мистецтва [8, с. 134].

Зважаючи на зазначені характеристики, можемо вважати, що за внутрішніми потребами для Я. Яциневича властиві гуманістичні особистісні риси етико-інтуїтивного інтроверта. За К. Філатовою, бажання сповідувати добро і справедливість «може сприяти тому, що гуманіст професійно займеться релігією» [8, с. 134]. Тому недивно, що Я. Яциневич став священиком та автором багатьох хорових духовних творів.

Звісно, не можемо відкидати наявність ознак й інших типів, адже жодна характеристика щодо певної особи, яка жила досить давно, не

12 Соціонічну теорію у 1970-х рр. запропонувала литовська вчена Аушра Аугустінавічюте. Теорія базується на вченнях К. Юнга, 3. Фрейда, А. Кемпінського. В основі соціонічної теорії - поняття «соціон», тобто сукупність шістнадцяти типів особистості, які попарно співвідносяться 3 восьми юнгівськими та діляться на квадри (чотири соціотипи, які об'єднуються на основі спільних психологічних та соціальних цінностей). 
може бути вичерпною. Сподіваємося, що подальші відкриття невідомих документів та вивчення більшої кількості музичних жанрів дадуть змогу доповнити особистісний портрет Я. Яциневича.

Таким чином, зважаючи на віднайдену інформацію з архівних матеріалів, виявлення гуманістичних рис інтровертного типу особистості Я. Яциневича, можемо зробити висновок, що упродовж життя композитор завжди залишався людиною з великої літери. Звісно, на уміння зберігати внутрішню рівновагу, а також людяне відношення до оточуючих, не могло не вплинути духовне виховання та моральні цінності Я. Яциневича, яких він дотримувався як священик, церковний регент та людина з церковного середовища.

\section{Література:}

1. Біографічні матеріали Я. М. Яциневича (1919-1944рp.). Інститут мистеитвознавства, фольклористики та етнології імені М. Рильського (IМФЕ). Ф. 19. Оп. 1. Спр. 1. 24 арк.

2. Корній Л. Історія української музичної культури : підручник / відп. ред. Л. Гнатюк. Київ : НМАУ ім. П. І. Чайковського, 2011. 720 с.

3. Лист Тичині П. Г. від Яциневича Я. (02.07.1942р.). Центральний державний архів-музей літератури $і$ мистецтвва Украйни (ЦДАМЛМ України). Ф. 464. Оп. 1. Спр. 7986. 3 арк.

4. Листи Кауфмана Л. С. Яциневич I. I. (19.02.1961-20.09.1965рp.). ЦДАМЛМ Украӥни. Ф. 4. Оп. 1. Спр. 112.8 арк.

5. Листи Яциневич I. I. до Кауфмана Л. С. (27.02.196108.09.1965 рр.). ЦДАМЛМ Украӥни. Ф. 4. Оп. 1. Спр. 256. 24 арк.

6. Музичне товариство імені М. Леонтовича. Видавничий відділ. Листування контори видавництва 3 організаціями та окремими особами УССР в справі надсилки музичної літератури (1 жовтня - 27 грудня 1925 р.). Інститут рукопису Національної бібліотеки України імені B. І. Вернадського (ІР НБУВ). Ф. 50. Оп. 1. Спр. 1551. 67 арк.

7. Протоколи загальних зборів і засідань адміністрації хору Університету святого Володимира (1904-1905 рр., 1914-1919 рр.). ІР НБУВ. Ф. 50. Оп. 1. Спр. 2011. 140 арк.

8. Филатова Е. Искусство понимать себя и окружающих. 208 с. URL: http://jagannath.ru/users_files/books/E._Filatova._Iskusstvo_ponimat sebya_i_okruzhayushih.doc (дата звернення: 5.06.2021).

9. Чекан Ю. Історія музики та історія музики. Часопис Haџ̧ioнальної музичної академї України імені П. І. Чайковського. 2017. Вип. 3(36). С. 47-54.

10. Юнг К. Психологические типы. 168 c. URL: https://www.litmir.me/ $\mathrm{br} / ? \mathrm{~b}=110043 \& \mathrm{p}=1$ (дата звернення: 5.06.2021). 